\title{
INFORMATION TECHNOLOGIES IN INCLUSIVE EDUCATION: FUTURE TEACHERS READINESS
}

\section{Chupakhina Svitlana ${ }^{1}$}

DOI: https://doi.org/10.30525/978-9934-571-89-3_31

Modern education is featured by information retrieval techniques of teaching that have come to change the explanatory-illustrative and reproductive methods of teaching. It is obvious today that psychological readiness to live in the information society, initial computer literacy, a culture of working with personal computers to solve educational problems have become an inalienable part of people's life regardless of their professional activity. At the same time new claims have emerged for educating handicapped citizens of our society. It is a well-known fact that success of any society is ensured by updating of the scientific, methodical and material support of education at all levels, including a professional one.

Investigating the problem of application of information technologies in teaching children with special educational needs, it is necessary to notice that academician A. Yershov has become the founder of computer literacy approach of teaching. The scientist asserted that there are also special "defectological" means of using information technologies in teaching children with development disorders or different forms of disability [2].

A wide range of application of information technologies in the modern world has set itself the task of purposeful teaching children with special educational needs to work on screen. Mastering the main methods of work, using the potential of a computer as an instrument of activity and as a means of training that corresponds to the age, level of development, interests, promotes and facilitates the inclusion of children with special educational needs in the society.

The substantive basis of the given problem is the formation of the readiness of future teachers for information technologies as an instrument for solving the development and correctional problems of teaching children with special educational needs in an inclusive educational environment.

In order to justify the problem of the readiness of future teachers, at various stages of the process of education informatization, to activities under inclusive education, it

\footnotetext{
${ }^{1}$ Vasyl Stefanyk Precarpathian National University, Ukraine
} 
is important to clarify the following concepts as "readiness for action", "information technology", "information computer technology", "inclusive education", "competence".

According to V. Zasenko, A. Kolupaieva, B. Moroz, V. Ovsianyk the introduction of methods of teaching based on information technologies has become an important direction of increasing efficiency and quality of correction and educational process under conditions of the special and inclusive education [2].

The didactic and methodical problems of informatization of educational process are discussed in the works by V. Boltianskyi, V. Bespalko, M. Zhaldak, V. Monakhov, V. Rozumovskyi, O. Spivakovskyi and others. Thepsychological and pedagogical aspects of information technologies application in the educational process have also become essential for our research (Yu. Mashbytsia, V. Zinchenko, $\mathrm{N}$. Talyzina and others). Experience and prospects of the use of information computer technologies abroad are discussed in works by R. Williams, K. Maklin, S. Peipert and others.

Taking into account scientific researches, we understand the future teachers' readiness for inclusive educational environment of modern schools as the result of professional training. We define it as a personal, psychological and pedagogical necessity to work as a teacher. The content of this activity is opened up through the complex of the formed system of knowledge, abilities and skills, personality meaningful and professionally important features, it is connected with ability to realize them in professional work and is determined by professional competences.

The general report of both Council and Commission on introduction of strategic limits of the European collaboration in the field of education and professional training (ET 2020) marked the importance and necessity of digital competence and great contribution of modern technologies in educational and teaching process as well as in management of education [4].

The following notion as "digital culture of a teacher" (i.e. acquiring and mastering a certain number of competences) has become of current interest (Figure 1) [4].

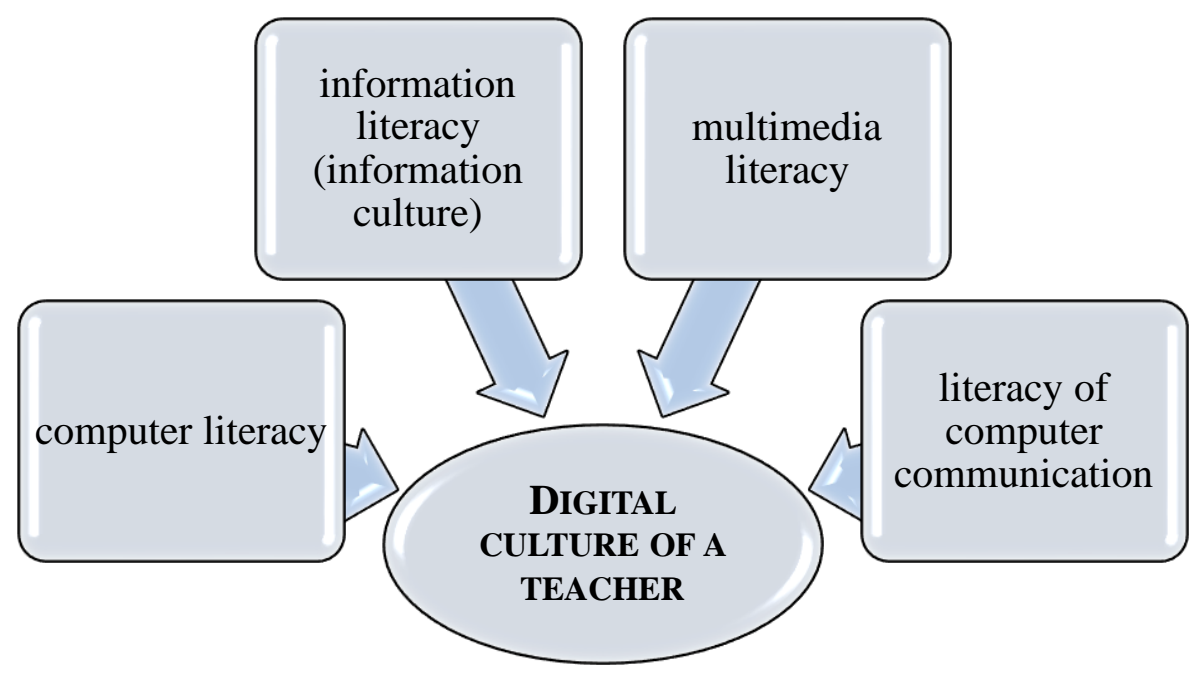

Figure 1. Information computer technologies - the teacher`s competences 
British Educational Communications and Technology Agency defines main advantages of application of information computer technologies in inclusive education (Figure 2) [2].

Computerized teaching technology is defined as a complex of theoretical knowledge of computer facilities, and also methods that regulate its application in teaching process [4].

Therefore, taking into account the possibilities of information computer technologies in working with children with special educational needs, it is necessary to create such a methodical system of teacher training that would provide certain professional digital competences (Figure 3).

Development of information technologies and their application in educational process of schools stimulates the origin of a new educational system that is able to provide educational services of high quality under conditions of reducing costs on education, however it requires teacher`s readiness to work under conditions of the marked system.

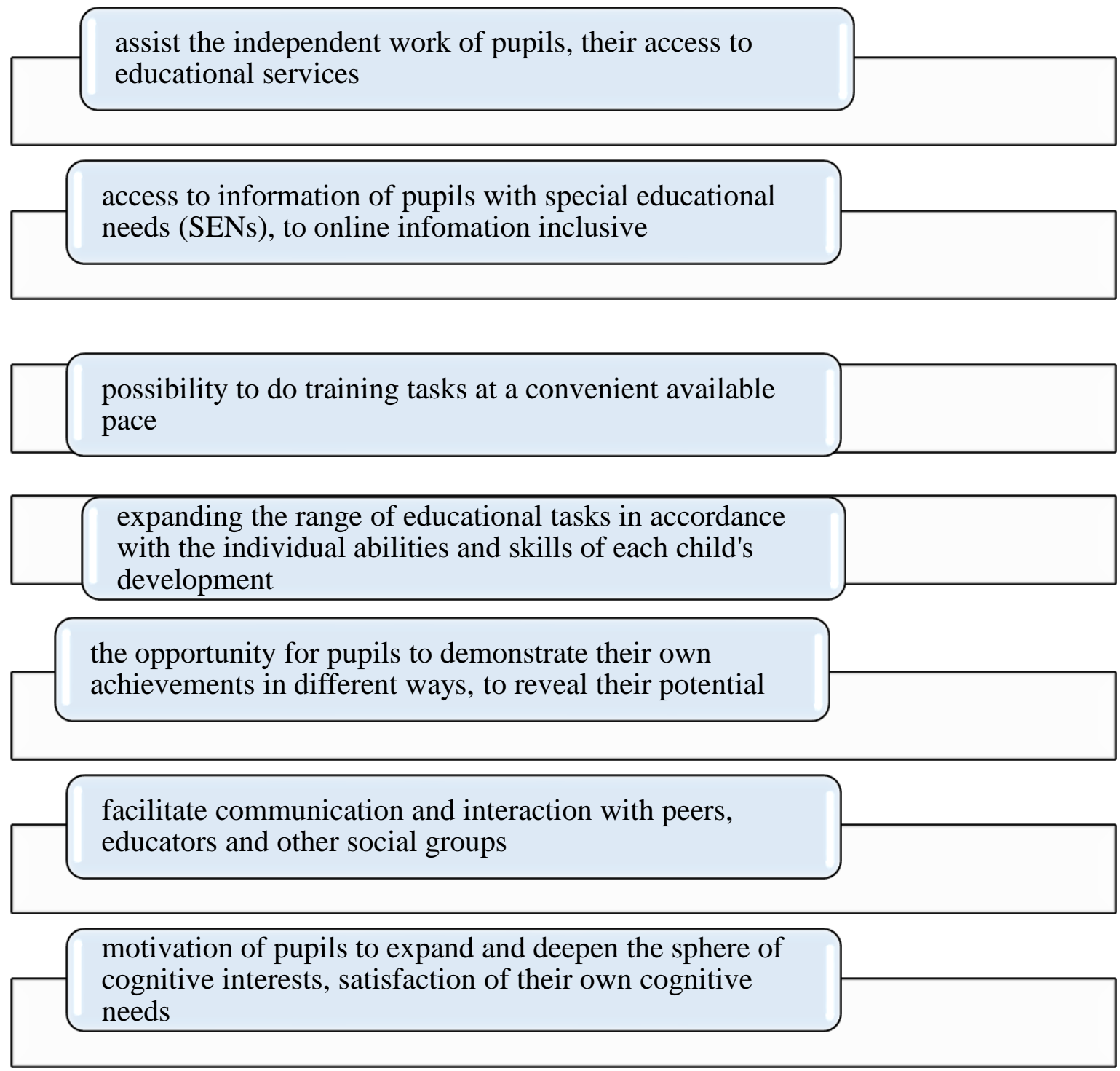

Figure 2. Information computer support of inclusive education 
Taking in to account all written above, application of information technologies in inclusive education should be considered as an important constituent oriented to form digital and inclusive competences of future teachers in the process of their professional training.

Diagnostic tests of readiness to application of information technologies in inclusive education in the direction of "readiness as a process" was carried out by taking the process of formation of information culture as a criterion. Assessment and identification of indicators - motivational tendencies of professional orientation, frequency of their realization, correlation of desirable and actual, information worldview, actualization of yourself as an expert in the field of application of information technologies in inclusive education, the consistency of a character "I AM-the subject of information computer activity" with another I AM.

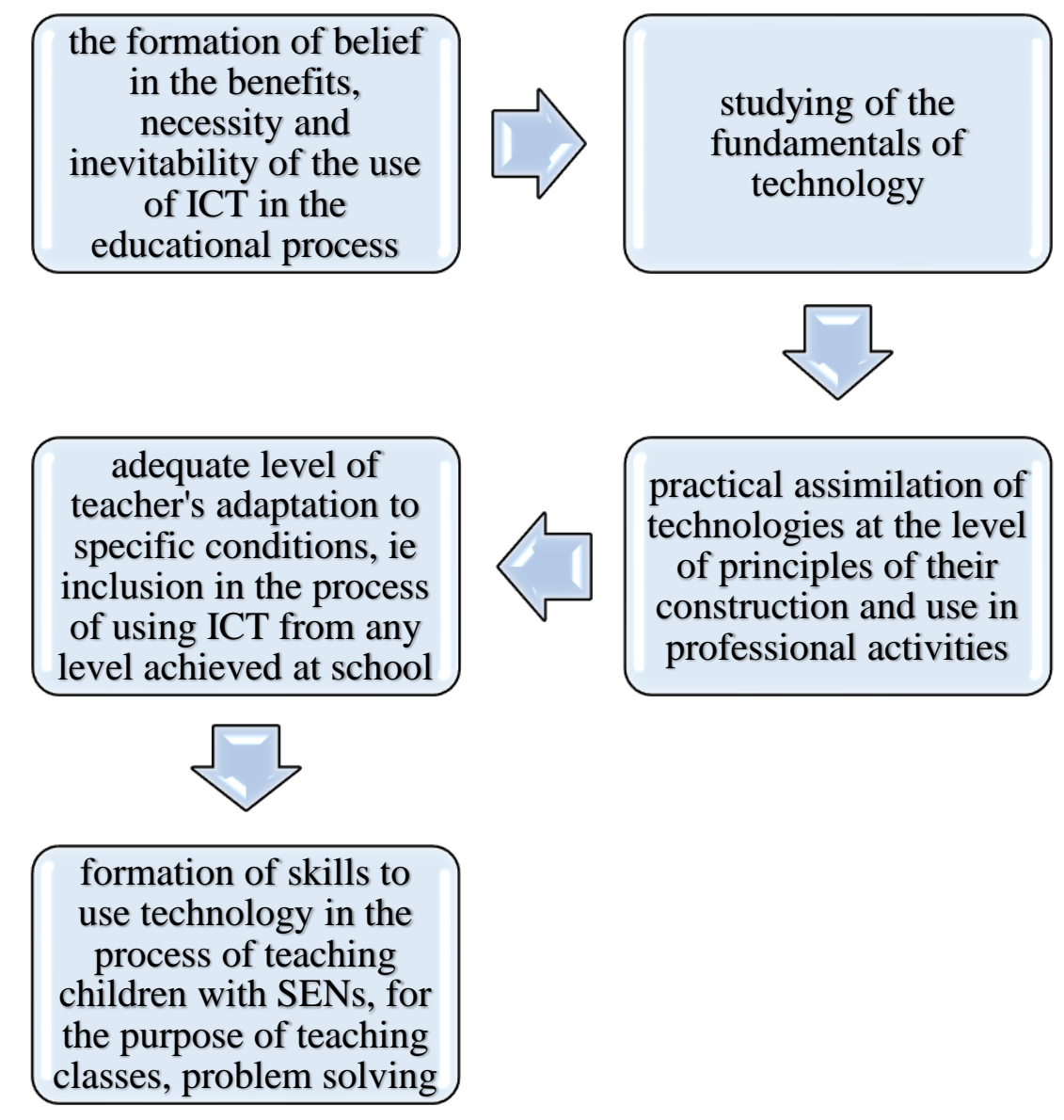

\section{Figure 3. Components of teacher`s digital competence of working with children with special educational needs}

This research revealed a rather low potential in the area of readiness for information and computer activities with the use of information technologies in working with children with special educational needs, although the growth or expansion of the potential of opportunities is aimed at increasing the level of readiness for the use of information technology in general. 
So, the results of the survey prove that the readiness of students to use information technology under inclusive education has insufficient level of formation, and therefore, the personal potential of the readiness to use technologies in the inclusive environment under new educational conditions requires more detailed substantiation, research and development of the system of training future teachers for professional activities.

This research does not exhaust the affected problem. Scientific researches can be continued in the following directions: peculiarities of conducting lessons using information technologies, specialized bulk-methodical software of the inclusive educational environment.

\section{References:}

1. Kademiia M.Yu., Shakhina I.Yu. (2011). Informatsiino-komunikatsiini tekhnolohii v navchalnomu protsesi: Navchalnyi posibnyk. [Information and communication technologies in the educational process: a manual]. Vinnytsia: Planer.

2. Shmyhol I. (2011). Cutnist ta struktura profesiinoi kompetentnosti pedahoha [Essence and structure of professional competence of the teacher]. URL: https://library.udpu.edu.ua/library_files/ probl_sych_vchutela/2011/4_1/visnuk_30.pdf

3. Kolupaieva A.A. (2010). Dity z osoblyvymy osvitnimy potrebamy ta orhanizatsiia yikh navchannia: nauk.-metod. posib. [Children with special educational needs and organization of their studies: science-method. manual]. Kyiv: Nauk. svit.

4. Zhaldak M.I., Shut M.I., Zhuk Yu.O., Dementiievska N.P., Pinchuk O.P., Sokoliuk O.M., Sokolov P.K. (2012). Multymediini systemy yak zasoby interaktyvnoho navchannia: posibnyk [Multimedia Systems as Interactive Learning Tools: A Guide]. Kyiv: Pedahohichna dumka.

5. Zakonodavstvo Ukrainy (2013). Natsionalna stratehiia rozvytku osvity v Ukraini na 2012-2021 roky [National Strategy for the Development of Education in Ukraine for 2012-2021]. URL: https://zakon2.rada.gov.ua /laws/show/344/2013 